\title{
Diet and abundance of bobcat (Lynx rufus) in the Potosino- Zacatecano Plateau, Mexico
}

\author{
Raúl Sánchez-González ${ }^{1}$ Anuar David Hernández-Saint Martin², Octavio Cesar Rosas-Rosas*3, and Juan García-Chávez \\ ${ }^{1}$ Escuela de Biología, Benemérita Universidad Autónoma de Puebla. Ciudad Universitaria, Boulevard Valsequillo y Av. San Claudio. \\ Edificio 112A, Col Jardines de San Manuel, CP. 72570, Puebla. Puebla, México. Email:juanga@correo.buap.mx (JHGC), raul. \\ sanchex@hotmail.com (RSG). \\ ${ }^{2}$ Colegio de Postgraduados-Campus San Luis Potosí. Iturbide 73. CP. 78621, Salinas de Hidalgo. San Luis Potosí, México. Email: \\ anuarhernandez@gmail.com (ADHS), \\ ${ }^{3}$ Colegio de Postgraduados Campus Puebla. Km. 125.5 carretera federal México-Puebla (actualmente Boulevard Forjadores de \\ Puebla), C.P. 72760, Puebla. Puebla, México. Email: octaviocrr@colpos.mx* (OCRR). \\ * corresponding author
}

The Potosino-Zacatecano Plateau (PZP) is characterized by a system of hills surrounded by ridges where the bobcat is the only wild felid; however, there is no information on the basic ecology of this species in this region. The objective of this work was to determine the diet and abundance of the bobcat in Cerro del Peñón Blanco, San Luis Potosí. The diet was inferred from the analysis of prey remains in feces; in addition, the minimum number of bobcats in the study area was estimated by camera traps placed in Cerro del Peñón Blanco, San Luis Potosí. Diet composition was expressed as percentage of occurrence. Individual bobcats were identified by the distinctive morphological characteristics of each. Seventy five scat samples were collected and analyzed. The diet included 14 taxa, with the rabbit Sylvilagus audubonii as the species most frequently consumed. The mouse Peromyscus spp. was the rodent species with the highest frequency of occurrence; however, no single species was dominant. We identified seven bobcat individuals: three males, three females and one of unknown sex. The bobcat diet allows inferring how this feline uses landscape in the study area, feeding on its main prey in foothills fragmented patches and complementing its diet with prey present in Peñón Blanco. The study area still provides sufficient prey base for the bobcat.

El altiplano Potosino-Zacatecano (APZ) se caracteriza por presentar un sistema de elevaciones rodeadas de lomeríos donde el gato montés es el único felino silvestre, sin embargo, no existe información sobre la ecología básica de esta especie en la región. El objetivo de este trabajo fue determinar la dieta y abundancia del gato montés en el cerro del Peñón Blanco, San Luis Potosí. La dieta se obtuvo del análisis de los restos de presas halladas en excretas y se estimó el número mínimo de gatos monteses en la zona de estudio por medio de trampas-cámara colocadas en el Cerro del Peñón Blanco, San Luis Potosí. La composición de la dieta se expresó como porcentaje de aparición. Los distintos individuos se identificaron por la presencia de características morfológicas distintivas. Se colectaron y analizaron 75 excretas. La dieta estuvo compuesta por 14 taxa, siendo la especie más común el conejo Sylvilagus audubonii. El ratón Peromyscus spp. fue la especie de roedor con mayor frecuencia de aparición, sin embargo, ninguna especie fue dominante. Se identificaron siete individuos de gato montés, tres machos, tres hembras y uno de sexo desconocido. La dieta del gato montés permite identificar como este felino usa el paisaje en la zona de estudio, alimentándose de su presa principal en las zonas bajas fragmentadas y complementando su dieta con presas presentes en el Peñón Blanco. La zona de estudio aún cuenta con una base de presas adecuada para el gato montés.

Keywords: camera-trapping; diet; feces; fragmentation; lagomorphs.

(C) 2018 Asociación Mexicana de Mastozoología, www.mastozoologiamexicana.org

\section{Introduction}

The Chihuahuan Desert is the largest arid zone in North America, and one with the highest biodiversity in the world (Hoyt 2002; Loa-Loza et al. 2009; Rzedowski 2005). Its southernmost portion corresponds to the Potosino-Zacatecano Plateau (PZP). This region is characterized by a system of elevations (e. g., ridges and rock outcrops) surrounded by hills and plains (INEGI 1985). Some of the elevations are covered by relicts of oak forest (Quercus potosina and Q. Greggi; Cabrera-Rodríguez 2015) that provide shelter for priority species for conservation in Mexico, such as the golden eagle (Aquila chrysaetos; Loa-Loza et al. 2009). However, many of these ridges and flat areas have been modified by anthropogenic activities such as cattle ranching, rainfed agriculture and mining (Martínez-Montoya et al. 2012).
The bobcat (Lynx rufus) is a felid whose historical distribution in Mexico stretched from the border with the United States south to the state of Oaxaca (Hall 1981). In Mexico, this species is not listed under any risk category (SEMARNAT 2010), although local bobcat populations have become isolated as a result of anthropic fragmentation processes (Lopez-González et al. 2015).

Most of the studies about bobcat in Mexico have analyzed their food habits, abundance and density in virtually undisturbed semi-desert and temperate habitats (LopezGonzález et al. 2015; Medélín and Bárcenas 2010). These studies reveal that the bobcat diet consists mainly of lagomorphs (Aranda et al. 2002; Delibes et al. 1997; Luna-Soria and López-González 2005; Medéllín and Bárcenas 2010).

The bobcat is the only wild felid currently inhabiting the PZP (Dalquest 1953, Martínez de la Vega et al. 2016). Its 
presence serves as an indicator of the conservation status of this region, as this feline requires territories with abundant prey base (Butrey 1979; McCord and Cardoza 1982; Sunquist and Sunquist 1989, 2000). In spite of its ecological importance, $L$. rufus is perceived to be a major predator of goats by local communities located in the PZP (MartínezMontoya et al. 2012). However, this claim has not been evaluated and there is a lack of baseline information on the ecology of the bobcat in PZP.

This work determined the diet of the bobcat across an area surrounded by a fragmented landscape, where ridges act as important relicts and shelters for biodiversity, specifically in El Peñón and other nearby elevations where the existing vegetation cover provides suitable habitats (Martínez-Montoya et al. 2012). This study contributes baseline information on the ecology of bobcat in PZP and its trophic relationship with goats.

\section{Materials and Methods}

Study area. The study was carried out in Cerro del Peñón Blanco, a mount located in the municipality of Salinas, to the northwest of the state of San Luis Potosi ( $\left.22^{\circ} 27^{\prime} 44^{\prime \prime} \mathrm{N},-10^{\circ} 43^{\prime} 00^{\prime \prime} \mathrm{W}\right)$, with an altitudinal range of 2,120 and $2,750 \mathrm{~m}$. It islocated $13 \mathrm{~km}$ southeast of the city of Salinas de Hidalgo, $8 \mathrm{~km}$ southwest of highway 57 and on the border between the states of San Luis Potosí and Zacatecas. Two communities are located in the mount foothills. El Alegre and San Juan sin Agua, each with less than 100 inhabitants (INEGI 1997; Figure 1).

The local climate is dry and semi-cold, with summer precipitation (June to September) and occasional drizzles in January; mean annual precipitation is $391 \mathrm{~mm}$. Mean annual temperature ranges between $16^{\circ} \mathrm{C}$ and $18^{\circ} \mathrm{C}$ (INEGI 2009). The vegetation communities include scrubland

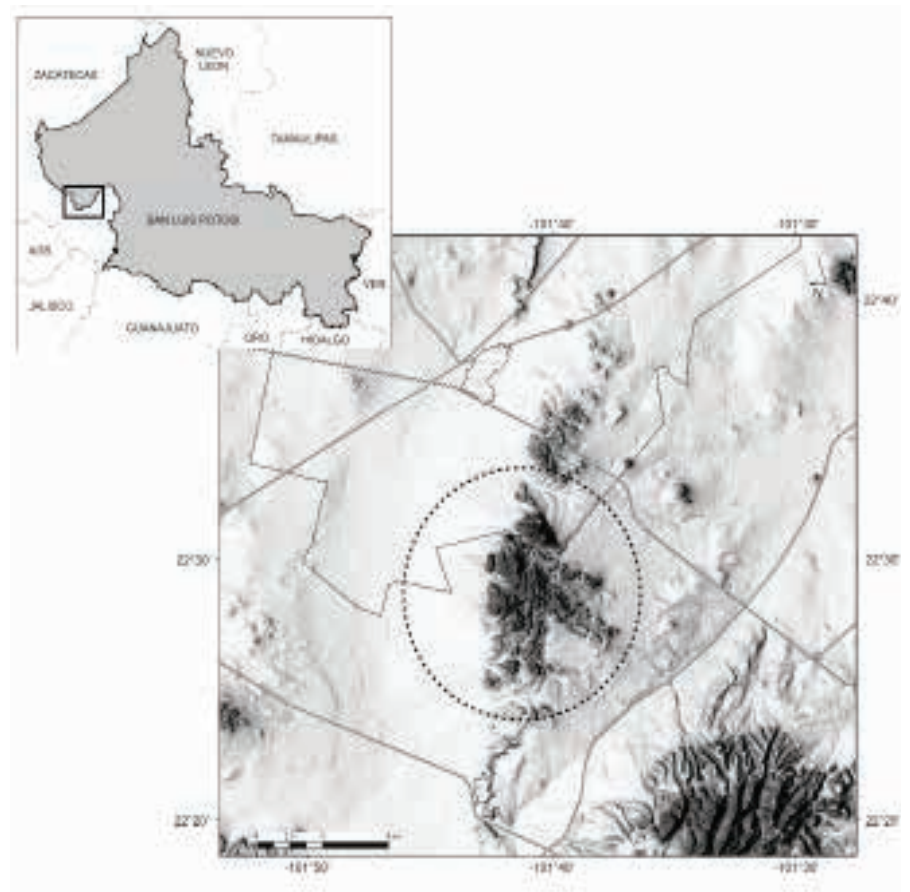

Figure 1. Location of Peñón Blanco in the Potosino-Zacatecano Plateau, Mexico. The dotted line marks the area of study. ("matorral crasicaule") and relicts of oak forest in the higher elevations (INEGI 1997). The original vegetation in the surrounding area was microphyll xeric shrub, yucca scrub, cardon scrub and cactus shrub (Rzedowski 2005). The dominant species are creosote bush (Larrea tridentata), alicoche (Opuntia bradtiana), mesquite (Prosospis laevigata), and Chinese palmtree (Yucca filifera). The local vegetation has been disrupted by excessive grazing by bovine cattle and goats, urbanization, mining operations and the opening up or expansion of terrestrial communication routes (Martínez-Montoya et al. 2012).

Diet Characterization. Diet components were quantified through the location, collection, identification and analysis of feces along dirt roads, livestock paths used by wildlife, and stream beds. Scat samples were collected once a week between June and November 2011 from nine latrines located throughout the study area. One week prior to the start of the field surveys, the area was walked to collect and dispose of all bobcat feces accumulated up to that time, to ensure that any feces analyzed in the study were one week old maximum.

Bobcat feces were differentiated in-situ from those of other carnivores also inhabiting the study area (e. g., coyote Canis latrans, and gray fox Urocyon cinereoargenteus) by comparing their physical characteristics and identifying the respective footprints and associated sign (sensu Aranda 2012). Any scats of questionable origin or weathered were discarded. Scat samples were placed in airtight Ziplock ${ }^{\mathrm{MR}}$ bags containing water and $10 \mathrm{~g}$ of powder detergent, and were soaked for at least 5 days. Afterwards, samples were washed under running water in 6-mm and 3- $\mathrm{mm}$ mesh sieves. Once washed, the content was oven-dried at $40^{\circ} \mathrm{C}$ for 24 hours.

Bones, feathers and scales were identified by comparison vs. reference collections and identification guides (Elbroch 2006; Scott and McFarland 2014). For the identification of hairs, slides were prepared to examine the medulla and cortical scales using the technique by Williamson (1951). Slides were compared against material from the collection of mammals of the Laboratory of Population Ecology, School of Biology, Benemérita Universidad Autónoma de Puebla. Components in scat samples were identified to the lowest taxonomic level possible.

The frequency and percentage of occurrence of the different species in feces was calculated. The percentage of occurrence was determined as: $\mathrm{PA}_{i}=\left(\mathrm{FA}_{\mathrm{i}} / \mathrm{N}\right) \times 100$. Where: $F A_{i}=$ Frequency of occurrence of species i. $\mathrm{N}=$ Total number of components in the scat samples analyzed.

Variations in the frequency of food items were determined by applying a G-test under the null hypothesis that species share the same frequency. In case of significant differences, paired G-tests were conducted for significant differences in the frequency of each item vs. the expected frequency (Zar 2010).

Estimate of the minimum number of individuals. In parallel with the collection of scats, eight simple camera-trap stations were installed (DeerCam ${ }^{\oplus}$ DC200, $35 \mathrm{~mm}$ ) across 
Peñón Blanco following the criteria by Heilbrun et al. (2003), distance between stations was 200 to $600 \mathrm{~m}$. Cameras were set to operate 24 hours with 5 minutes between triggers. Due to the lack of trees in the study site, cameras were installed on wooden stakes at $30 \mathrm{~cm}$ above the ground. No baits were used in any station.

The minimum number of individuals during the sampling period was determined. The distinctive traits of individual bobcats used in the analysis of photographs included spot pattern, scars, facial ruff shape and color, sex and body size (Heilbrun et al. 2003, 2006; Figure 2). The identification and quantification of captures-recaptures were conducted according to the guidelines proposed by Heilbrun et al. (2003), namely a) only photographs of an individual bobcat that could not be associated with another captured previously were considered as initial captures; b) recaptures were determined even in cases where there were no photographs of the complete individual, provided its identity could be fully established; c) any poor-quality photographs that could not be classified as an initial capture or a recapture were discarded; d) In all cases, at least three natural characteristics (e. g., tail stripes, scars, face marks, or facial ruff patterns) were used to identify individuals and to determine recaptures; e) the identification of a single different trait was considered as sufficient to consider that two photographs represented different individuals.

\section{Results}

A total of 75 scat samples of $L$. rufus were collected and analyzed, from which food items belonging to 14 different taxa were identified. Mammals were the most frequent prey, with $11 \mathrm{spp}$. To a lesser extent, the diet also included birds, reptiles and invertebrates (Table 1).

Differences were observed in the frequency of occurrence of the various taxa in the diet $(G=114.73$; $\mathrm{g}$. $\mathrm{l} .=13$; $P=0.001$ ). The rabbit $S$. auduboni was the species with the highest percentage of occurrence. The frequency of occurrence of this lagomorph in feces was significantly higher relative to any other species $(P<0.001)$. The raccoon (Procyon lotor) and invertebrates were consumed with lowerthan-expected frequencies $(P<0.05)$. No rodent species was consumed more frequently than any other prey taxa. No goat remains were identified in any of the scat samples analyzed.

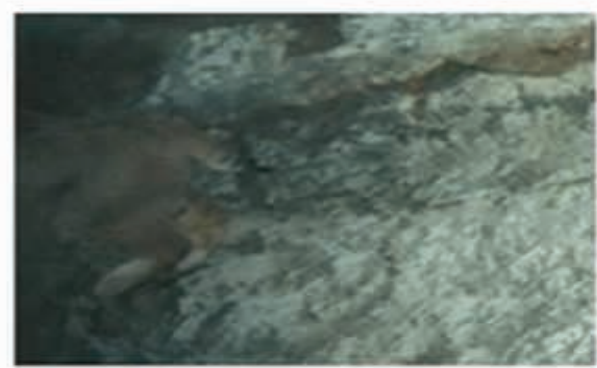

LD01 - 30/aro

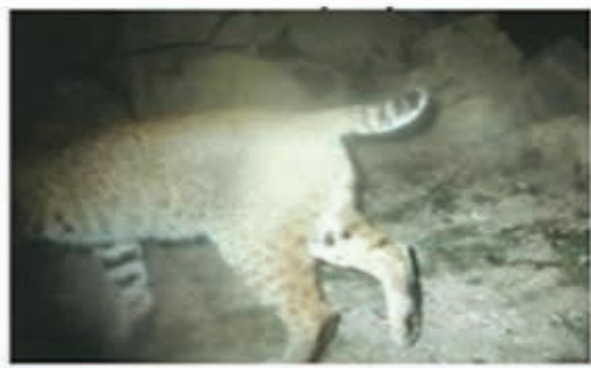

LHO2 - 20/sept

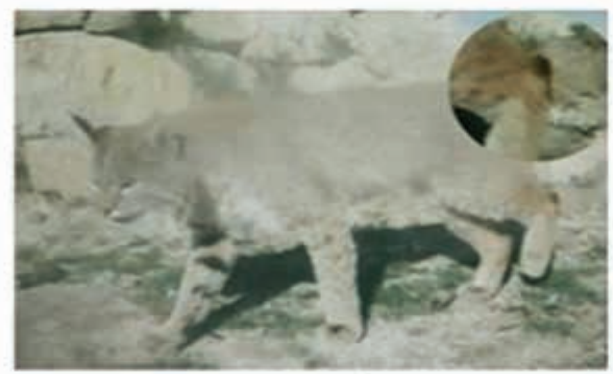

LM02 - 9/oct

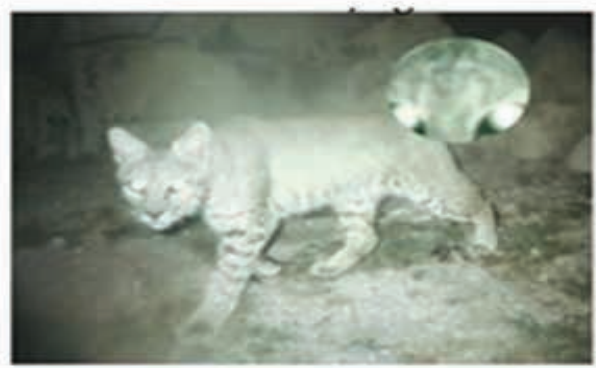

LH01 $-8 /$ sept

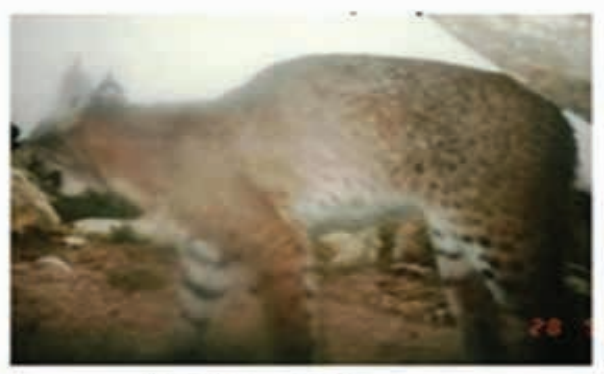

LH03 - 26/sept

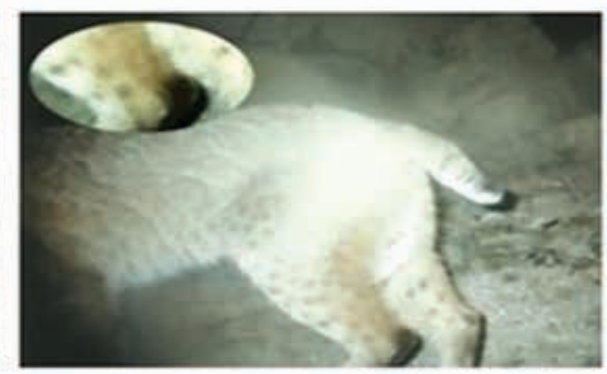

LMO2 - 7/nov

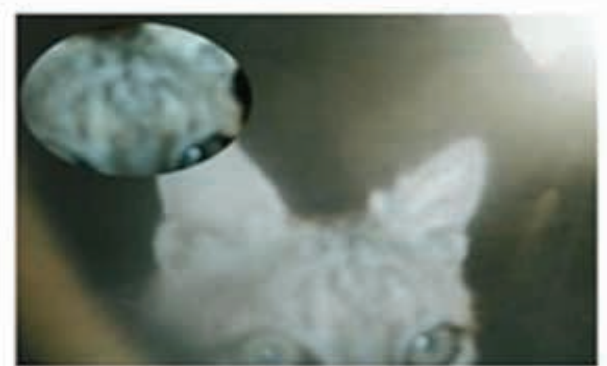

LH01-9/oct

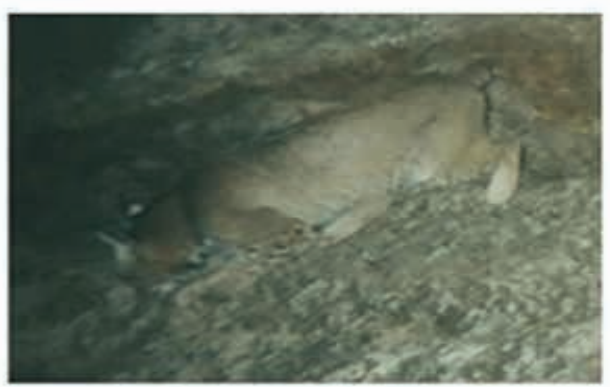

LM01 - 6/oct

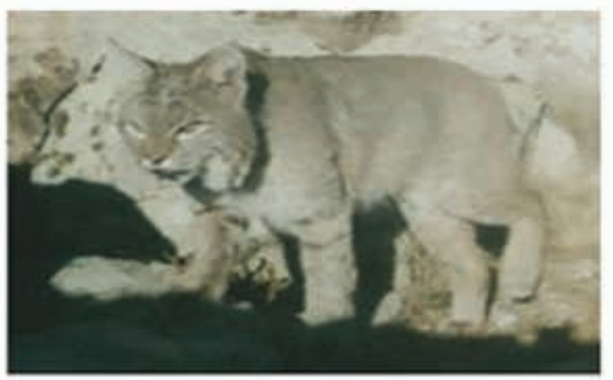

LM03 - 12/oct

Figure 2. Bobcat individuals photographed in the Peñón Blanco in the Potosino-Zacatecano Plateau, Mexico 
Table 1. Diet of the bobcat at Peñón Blanco, Potosi-Zacatecas Plateau, Mexico.

\begin{tabular}{lcc}
\hline Species & Frequency of occurrence & Percentage of occurrence \\
\hline Mammals & & \\
Rodents & 13 & \\
Chaetodipus nelsoni & 19 & 5.1 \\
Neotoma mexicana & 19 & 7.5 \\
Peromyscus boylii & 11 & 7.5 \\
Peromyscus maniculatus & 28 & 4.3 \\
Peromyscus sp. & 23 & 11.1 \\
Peromyscus truei & 21 & 9.1 \\
Otospermophilus variegatus & & 8.3 \\
Lagomorphs & 23 & \\
Lepus callotis & 58 & 9.1 \\
Sylvilagus audubonii & & 22.9 \\
Carnivores & 2 & 0.8 \\
Procyon lotor & 11 & 4.4 \\
Unidentified Mammal & & \\
Birds & 10 & 3.2 \\
Unidentified bird & & \\
REPTILES & 8 & \\
Sceloporus sp. & & \\
Invertebrates & 7 & \\
Invertebrates & & \\
\hline & & \\
\hline
\end{tabular}

A sampling effort of 630 trap-nights yielded 32 separate photographs (sensu O'Brien et al. 2003) of nine species of wild animals (Table 2). Twelve of these photographs were of bobcat (Table 2), with nine being useful for the identification of individual specimens. The remaining photographs were excluded due to poor image quality, showing an individual in a position that restrained an accurate observation of its characteristics, or for being partial pictures that hindered a reliable identification. As a minimum, three males, three females and one individual of undetermined sex were identified. All individuals, except for female LH1 and male LM02, were photographed only on one occasion. Recaptures occurred in the same camera-trapping site.

\section{Discussion}

The bobcat is the top predator in desert ecosystems where large carnivores (i. e., Puma concolor) have been eliminated; hence, its diet is expected to consist of a broad variety of prey types available in the ecosystem (Sergio et al. 2006). The results of the diet composition were very similar to observations reported from non-fragmented desert environments in the United States (Fritts and Sealander 1978; Jones and Smith 1979; Koehler and Hornocker 1991) and Mexico (Aranda et al. 2002; Delibes et al. 1997; Luna and López 2005).

The analysis of the diet makes possible to identify how the bobcat uses the landscape in the study area. In this case, rabbits were the group with the highest percentage of occurrence in the feces analyzed, with S. auduboni being best adapted to flat areas and hills (Bond et al. 2002). This
Table 2. Photographs of wildlife captured at Peñón Blanco, Potosino-Zacatecano Plateau, Mexico.

\begin{tabular}{lcc}
\hline Species & Independent Photographs & IAR* \\
\hline Canis latrans & 1 & 0.16 \\
Canis lupus familiaris & 1 & 0.16 \\
Conepatus leuconotus & 2 & 0.32 \\
Geococcyx californianus & 3 & 0.48 \\
Lynx rufus & 12 & 1.90 \\
Procyon lotor & 8 & 1.27 \\
Sciurus sp. & 1 & 0.16 \\
Otospermophilus variegatus & 1 & 0.16 \\
Urocyon cinereoargenteus & 3 & 0.48 \\
\hline Total & 32 & \\
\hline * sensu O' Brien et al. 2003. & &
\end{tabular}

suggests that the bobcat forages mainly in the lower elevations of Peñón Blanco. Rabbits and hares are species that can tolerate the fragmentation of their habitat; however, this fragmentation increases the risk of being consumed by predators (Villafuerte et al. 1997). In this sense, the fragmentation adjacent to Peñón Blanco apparently does not affect the feeding ecology of the bobcat, since the conditions resulting from habitat fragmentation substitute the preferential consumption of lagomorphs.

The consumption of other prey types such as the rock squirrel, Otospermophilus variegatus, and lizards of the genus Sceloporus, which are abundant in rocky outcrops across Peñón Blanco (Martínez-Montoya et al. 2012), demonstrate the importance of this elevation has as a source of secondary prey items for the bobcat. The consumption of rock squirrels has been recorded in sites with rocky outcrops similar to Peñón Blanco, as is the case of Plomito in Sonora (Aranda et al. 2002), Sierra del Ajusco (Romero 1993) and La Malinche National Park (Cortés 1998).

As a group, rodents are key components of the diet of the bobcat in the study area. This group is particularly abundant in sites covered by grasslands interspersed with patches of scrub vegetation and rocky outcrops (Mellink 1991), which are located in the foothills of Peñon Blanco (INEGI 1985). The bobcat is an opportunistic hunter that forages on the most abundant prey items in its habitat (Lopez-Vidal et al. 2014), such as mice of the genus Peromyscus. Altogether, these mice accounted for $32 \%$ of the diet, indicating that they are important prey for the bobcat in this region. These rodents likely serve as alternate prey items in areas where lagomorphs are relatively scarce. This has been reported for central Mexico, an area where rabbits are scarce due to hunting, leading to Peromyscus becoming the most important prey of bobcats (Cortés 1998).

The opportunistic behavior of $L$. rufus in the study area is highlighted by the presence of raccoon in its diet. This is the first record of bobcat predating on raccoon across its distribution range. The raccoon is a species strongly associated with water bodies (Valenzuela 2005), so that the presence 
of temporary streams flowing down from Peñón toward lowlands, where some ponds remain even in the dry season, may favor their presence to the point of being the second most abundant species recorded by camera traps.

This study recorded no evidence of the predation of goats or sheep by bobcat. The predation of livestock by bobcat is poorly documented; therefore, it is considered as a species with low risk of conflict with humans (Inskip and Zimmermann 2009). The absence of livestock items in the diet suggests that anecdotic claims about this species as a predator of livestock may be a misperception of the local inhabitants rather than reflecting a genuine impact. Moreover, this finding also suggests that, in spite of the current fragmentation, the landscape in the study area still provides a sufficient prey abundance that allows maintaining the local bobcat population. However, the increase in grazing intensity by goat herds that roam freely across Peñón Blanco and its surrounding areas could lead to a decline in the abundance of the local populations of rodents and lagomorphs (Vorhies and Taylor 1933), resulting in the possibility of predation on livestock by bobcat.

The presence of seven bobcat individuals during the period of study highlights the importance of Peñón Blanco as a habitat for this species. Peñón Blanco, one of the highest elevations across an area of $2,000 \mathrm{~km}^{2}$, has features that are preferred by the bobcat to establish burrows and daytime resting sites (e. g., rugged topography and presence of abundant rocky formations; Romero 2005), so it may be the site of confluence of the territories of various individuals. This hypothesis is further supported by the presence of abundant latrines $(n=15)$ in the highest sites of Peñón, where at least two individuals were photographed while performing territorial marking.

\section{Acknowledgments}

We thank J. Pimentel López, head of the San Luis Potosi Campus of Colegio de Postgraduados for the assistance provided for the conduct of this work, and the support of the Región de Microatención Prioritaria (MAP) San Juan sin Agua at San Luis Potosi Campus of Colegio de Postgraduados. In addition, we thank J. F. Martinez Montoya from the same institution for the scholarship granted to the first author. Thanks also to the inhabitants of San Juan sin Agua for their support during field work. Finally, we would like to thank E. Mendoza Ramirez and three anonymous reviewers who enriched the present work with their comments and observations. María Elena Sánchez-Salazar translated the manuscript into English.

\section{Literature cited}

ARANDA, M. 2012. Manual de rastreo de mamíferos silvestres de México. Comisión Nacional para el Conocimiento y Uso de la Biodiversidad. Ciudad de México, México.

Aranda, M., O. C. Rosas-Rosas, J. D. J. Ríos, and N. García. 2002. Análisis comparativo de la alimentación del gato montés (Lynx rufus) en dos diferentes ambientes de México. Acta
Zoológica Mexicana (n. s.) 87:99-109.

Bond, B. T., L.W. BuRger JR, B. D. LeOPOLD, J. C. Jones, AND K. D. GOdWIN. 2002. Habitat use by cottontail rabbits across multiple spatial scales in Mississippi. The Journal of Wildlife Management 66:1171-1178.

Buttrey, G. W. 1979. Food habits and distribution of the bobcat, Lynx rufus rufus (Schreber), on the Catoosa wildlife management area. Pp 87-91 in Proceedings of the Bobcat Research Conference National Wildlife Federation Scientific and Technical Series 6.

Cabrera-Rodríguez, A. 2015. Distribución y diversidad del género Quercus en el altiplano Potosino-Zacatecano. Tesis de Maestría. Colegio de postgraduados.

CoRTÉs, L. A. 1998. Variación anual de la dieta del gato montés Lynx rufus escuinapae (Carnivora: felidae), en el parque nacional Malinche, Tlaxcala, México. Tesis profesional. Universidad Nacional Autónoma de México.

DALQUEST, W.W. 1953. Mammals of the Mexican state of San Luis Potosi. Louisiana State University Press. Louisiana, U. S. A.

Delibes, M., AND F. HiRAldo. 1987. Food habits of the bobcat in two habitats of the southern Chihuahuan desert. The Southwestern Naturalist 457-461.

Delibes, M., S. C. Zapata, M. C. Blázquez, and R. Rodríguez-Estrella. 1997. Seasonal food habits of bobcats (Lynx rufus) in subtropical Baja California Sur, Mexico. Canadian Journal of Zoology 3:478-483.

ELBROCH, M. 2006. Animal skulls: a guide to North American species. Stackpole books. Washington, U. S. A.

FritTs, S. H., and J. A. Sealander. 1978. Diets of bobcats in Arkansas with special reference to age and sex differences. The Journal of Wildlife Management 42:533-539.

HALL, R. E. 1981. The mammals of North America. 2nd ed. John Wiley and Sons. New York, U. S. A.

Heilbrun, R. D., L. J. Silvy, M. J. Peterson, and M. E. Tewes. 2006. Estimating bobcat abundance using automatically triggered cameras. Wildlife Society Bulletin 34:69-73.

Heilbrun, R. D., N. J. Silvy, M. E. Tewes, and M. J. Peterson. 2003. Using automatically triggered cameras to individually identify bobcats. Wildlife Society Bulletin 31:748-755.

Hort, A. C. 2002. The Chihuahuan Desert: Diversity at Risk. Endangered Species Bulletin, 2:16-17.

Instituto Nacional de Estadística y Geografía. 1985. Síntesis geográfica del estado de San Luis Potosí. Instituto Nacional de Estadística y Geografía. Ciudad de México, México.

Instituto Nacional de Estadística y Geografía. 1997. Salinas: Estado de San Luís Potosí. Cuaderno Estadístico Municipal. Instituto Nacional de Estadística y Geografía. Ciudad de México, México. Instituto Nacional de Estadística y Geografía. 2009. Prontuario de información geográfica municipal de los Estados Unidos Mexicanos: Salinas, San Luis Potosí. Instituto Nacional de Estadística y Geografía. Ciudad de México, México.

INSKIP, C., AND A. ZIMMERMAnN. 2009. Human-felid conflict: a review of patterns and priorities worldwide. Oryx 43:18-34.

JONES, J. H., AND N. S. SMITH. 1979. Bobcat density and prey selection in central Arizona. The Journal of Wildlife Management 43:666-672.

Koenler, G. M., and M. G. Hornocker. 1991. Seasonal resource use among mountain lions, bobcats, and coyotes. Journal of Mammalogy 72:391-396. 
Litvaitis, J. A., J. A. Sherburne, and J. A. Bissonette. 1986. Bobcat habitat use and home range size in relation to prey density. The Journal of Wildlife Management 50:110-117.

LOA-LozA, E. 2009. Áreas prioritarias para el manejo y conservación en el estado de San Luis Potosí, México. Secretaria de Desarrollo Agropecuario y Recursos Hidraulicos. San Luis Potosí, México.

López-González, C. A., D. Ávila-Aguilar, y M. F. Cruz-Torres. 2015. Abundancia del gato montés (Lynx rufus escuinapae J. A. Allen, 1903) en el Parque Nacional el Cimatario, Querétaro, México. Acta Zoológica Mexicana (n. s.) 31:138-140.

López-Vidal, J. C., C. Elizalde-Arellano, L. Hernández, J. W. Laundré, A. González-Romero, and F. A. Cervantes. 2014. Foraging of the bobcat (Lynx rufus) in the Chihuahuan Desert: generalist or specialist? The Southwestern Naturalist 59:157-166.

LUNA-SORIA, H., AND C. A. LÓPEZ-GonzÁlez. 2005. Abundance and food habits of cougars and bobcats in the Sierra San Luis, Sonora, Mexico. United States Department of Agriculture Forest Service Proceedings RMRS-P-36, 416.

Martínez de la Vega G., G. García-Marmolejo, J. Luévano-Esparza, R. García-Morales, C. E. Rangel-Rivera, and J. A. Ascanio-Lárraga. 2016. La mastofauna en San Luis Potosí: conocimiento, diversidad y conservación. Pp. 367-404 in Riqueza y Conservación de los Mamíferos en México a Nivel Estatal (Briones-Salas, M., Y. Hortelano-Moncada, G. Magaña-Cota, G. Sánchez-Rojas, and J. E. Sosa-Escalante, eds.). Instituto de Biología, Universidad Nacional Autónoma de México, Asociación Mexicana de Mastozoología A. C. and Universidad de Guanajuato. Ciudad de México, México.

Martínez-Montoya J. F., J. Palacio-Núñez, G. Olmos-Oropeza, V. Ruiz-Vera, J. Zavala-Cruz, A. Amante-Orozco, O. C. Rosas-Rosas O, and D. Talavera-Magaña. 2012. Caracterización física, biótica y socioeconómica del altiplano Potosino oeste. Línea prioritaria de investigación no 1 (manejo sustentable de recursos naturales) del Colegio de Postgraduados. Salinas de Hidalgo, México.

McCord, C. M. And J. E. Cardoza.1982. Bobcat and lynx. Pp 728766, in Wild mammals of north America: biology, management and economics (Chapman, J. A., and G. A Feldhamer, Eds). Johns Hopkins University Press. Baltimore, U. S. A.

Medellín, R. A., AND H. V. BÁrcenas. 2010. Estimación de la densidad poblacional y dieta del gato montés (Lynx rufus) en Aguascalientes y el Distrito Federal, México. Universidad Nacional Autónoma de México. Instituto de Ecología. Informe final SNIB-CONABIO proyecto es003. Ciudad de México, México.

Meluink, E. 1991. Rodent communities associated with three traditional agroecosystems in the San Luis Potosi plateau, Mexico. Agriculture, Ecosystems and Environment 33:363-375. O'Brien, T. G., M. F. Kinnaird, AND H.T.WiBISONO. 2003. Crouching tigers, hidden prey: Sumatran tiger and prey populations in a tropical forest landscape. Animal Conservation Forum 6:131-139.

ROMERo, F. 1993. Análisis de la alimentación del lince (Lynx rufus escuinapae) en el centro de México. Avances en el estudio de mamíferos de México, Publicaciones Especiales 1:217-230.

Romero, F. 2005. Lince, gato montés. Pp. 362-364 in Los mamíferos silvestres de México (Ceballos, G., and G. Oliva, Coords). Fondo de Cultura Económica. Ciudad de México, México.
Rzedowskı, J. 2005. Vegetación de México. Comisión Nacional para el Conocimiento y Uso de la Biodiversidad. Primera edición digital. Ciudad de México, México.

SCOtT, S. D., AND C. MCFARLAND. 2014. Bird feathers: a guide to North American species. Stackpolebooks. Washington, U. S. A. Secretaria de Medio Ambiente y Recursos Naturales. 2010. Norma Oficial Mexicana NOM-059-SEMARNAT-2010, Protección ambiental-especies nativas de México de flora y fauna silvestres-categorías de riesgo y especificaciones para su inclusión, exclusión o cambio-lista de especies en riesgo. Diario Oficial de la Federación (segunda sección) del 30 de diciembre de 2010.

Sergio, F., I. A. N. Newton, L. Marchesl, and P. Pedrini. 2006. Ecologically justified charisma: preservation of top predators delivers biodiversity conservation. Journal of Applied Ecology 43:1049-1055.

SUNQUIST, M. E., AND F. SUnquIST. 1989. Ecological constraints on predation by large felids. Pp. 283-301 in Carnivore behavior, ecology, and evolution (J. L. Gittleman, Ed). Cornell University Press. New York, U. S. A.

Sunquist, M. E, AND F. Sunquist. 2000. Wild cats of the world. The University of Chicago Press. Chicago, U. S. A.

Valenzuela, D. 2005. Mapache. Pp. 415-417 in Los mamíferos silvestres de México (Ceballos, G., and G. Oliva, Coords). Fondo de Cultura Económica. Ciudad de México, México.

Villafuerte, R., J. A. Litvaitis, and D.F. Smith. 1997. Physiological responses by lagomorphs to resource limitations imposed by habitat fragmentation: implications for condition-sensitive predation. Canadian Journal of Zoology 75:148-151.

Vorhies, C. T., AND W.P. TAYLOR. 1933. The life histories and ecology of jack rabbits, Lepus alleni and Lepus californicus ssp., in relation to grazing in Arizona. College of Agriculture, University of Arizona. Tucson, U. S. A.

Williamson, V. H. H. 1951. Determination of hairs by impressions. Journal of Mammalogy 32:80-84.

$Z_{A R}$, J.H. 2010. Biostatistical analysis. Pearson Education. New Jersey, U. S. A.

Associated editor: Eduardo Mendoza

Submitted: April 27, 2017; Reviewed: August 27, 2018;

Accepted: February 25, 2018; Published on line: April 22, 2018. 